\title{
Synthesis and Antileishmanial Activity of Lipophilic Aromatic Aminoalcohols
}

\author{
Roberta Novaes Reis Corrales ${ }^{1}$, Liliane Sena Pinheiro², Elaine Soares Coimbra ${ }^{2}$, \\ Adilson David Da Silva ${ }^{1} *$, and Mireille Le Hyaric ${ }^{1}$ \\ ${ }^{1}$ Departamento de Química, I.C.E., Universidade Federal de Juiz de Fora, Campus Universitário, Juiz \\ de Fora, Minas Gerais, Brasil; ${ }^{2}$ Departamento de Parasitologia, Microbiologia e Imunologia, I.C.B., \\ Universidade Federal de Juiz de Fora, Campus Universitário, Juiz de Fora, Minas Gerais, Brasil \\ E-mail: robertacnr@bol.com.br; liliane.senapinheiro@yahoo.com.br; elaine.coimbra@ufff.edu.br; \\ david.silva@ufjf.edu.br; mireille.hyaric@ufjf.edu.br
}

Received February 4, 2010; Revised April 26, 2010; Accepted May 9, 2010; Published June 14, 2010

In this work, we report on the preparation and evaluation of the in vitro antileishmanial activity of a series of lipophilic aromatic aminoalcohols. All compounds were assessed for their in vitro antiproliferative activity against promastigotes of three Leishmania species. The most lipophilic aminoalcohols bearing an aliphatic moiety with eight to 12 carbon atoms displayed a good activity against $L$. amazonensis and $L$. major, and two of them also showed antiproliferative activity against $L$. chagasi. The best results were obtained for the $\mathbf{N}$-dodecanoyl ethylenediamine derivative and for $\mathbf{N}$-decyl aminoalcohol $\left(\mathrm{IC}_{50}=5.2\right.$ and $0.7 \mu \mathrm{M}$, respectively).

KEYWORDS: aminoalcohols, antileishmanial activity, Leishmania, polyamines

\section{INTRODUCTION}

Leishmaniasis is an infective parasitic disease, endemic in the American, African, and Asian tropical countries, with an estimated 1.5-2 million cases per year in 88 countries, and it is classified as one of the "most neglected diseases"[1]. Leishmaniasis is a major vector-borne disease caused by more than 20 species of the protozoan genus Leishmania[2]. Human leishmanial infection can manifest itself in three most common forms: cutaneous leishmaniasis, mucocutaneous leishmaniasis, or visceral leishmaniasis (commonly known as Kala-azar). This last clinical manifestation produces severe weight loss, anemia, and systemic impairment, leading to death when untreated. The fatality rate is almost $100 \%$ in children and women from poor families[3,4].

Drugs currently in use, such as the antimony derivative glucantime, bis-amidines, pentamidine, and the glycomacrolide amphotericin B, display high liver and heart toxicities and lead to clinical resistance after a few weeks of treatment[5,6]. Other limitations to the use of these drugs include the cost of the treatment and the need for parenteral administration[5]. All these factors contribute to compliance difficulties and treatment failures, and there is a real need to discover new potent and selective agents, either natural or synthetic, for the treatment of this increasing parasitosis.

Leishmania and other protozoa belonging to the trypanosomatid family have distinct polyamine metabolisms compared to mammalian cells, opening the possibility of identifying new targets for 
antiparasitic drug development[7,8,9,10,11]. Polyamines such as putrescine and spermidine are aliphatic organic compounds that play vital roles in several eukaryotic cellular processes, such as growth, protein/nucleic acid synthesis, and macromolecular biosynthesis[12,13]. Trypanosomes are unusual organisms in that spermidine is also used in the synthesis of trypanothione, which is both unique and essential to those parasites. The cloning, expression, purification, and crystallization of trypanothione reductase in Leishmania species was recently reported[14,15].

We describe in the present paper the synthesis of lipophilic aromatic aminoalcohols and their in vitro biological activities against Leishmania promastigote forms. These types of compounds, bearing a covalent bonded aliphatic chain attached to an aminoalcohol fragment, could interact with membrane lipids and be transported into the cytoplasm where they can possibly interfere with the lipid or polyamine transport or metabolism of the parasite[16].

\section{MATERIALS AND METHODS}

\section{Chemicals}

The aminoalcohol derivatives 3a-d were prepared in 63-80\% yield by treatment of 2-phenylethylbromide 1 with aminoalcohols 2a-d, as previously described[17,18,19,20] (Scheme 1). The phenethyl glycidyl ether 4, prepared using a simple synthetic method[20], was treated in ethanol at $70^{\circ} \mathrm{C}$ for $24 \mathrm{~h}$ with the aminoalcohols 2a-d (Scheme 2), the amides 6a-c[21], and with the amines 8a,b, leading, respectively, to aminoalcohols 5a-d, 7a-c, and 9a,b in 56-84\% yield (Scheme 3). All the compounds were characterized by NMR and IR spectroscopy[22].

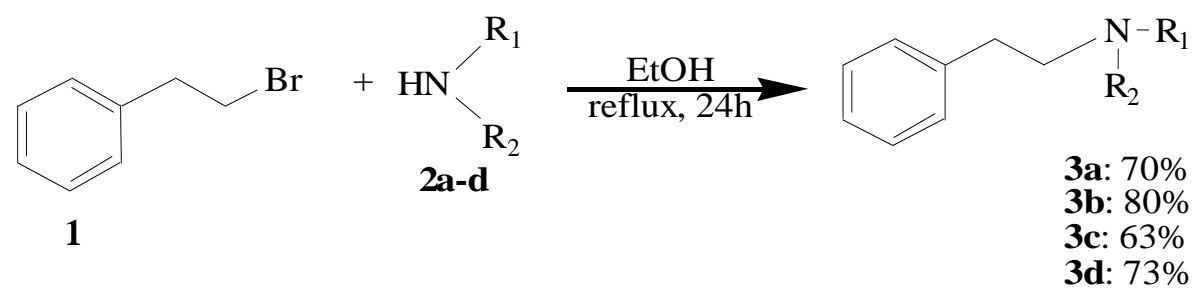

a- $\mathrm{R}=\mathrm{H} ; \mathrm{R}_{1}=\left(\mathrm{CH}_{2}\right)_{2} \mathrm{OH} ; \quad$ b- $\mathrm{R}=\mathrm{H} ; \mathrm{R}_{1}=\left(\mathrm{CH}_{2}\right)_{3} \mathrm{OH} ; \quad$ c- $\mathrm{R}=\mathrm{H} ; \mathrm{R}_{1}=\mathrm{C}\left(\mathrm{CH}_{3}\right)_{2} \mathrm{CH}_{2} \mathrm{OH} ; \quad$ d- $\mathrm{R}=\mathrm{R}_{1}=\mathrm{CH}_{2} \mathrm{CH}_{2} \mathrm{OH}$

SCHEME 1. Synthesis of aromatic aminoalcohols 3a-d.<smiles>OCCc1ccccc1</smiles>

1- $\mathrm{NaH}, \mathrm{THF}, \mathrm{O}^{\circ} \mathrm{C}$ 2- epichlorhydrin, r.t. $60 \%$
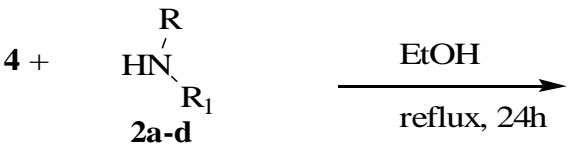<smiles>c1ccc(CCOCC2CO2)cc1</smiles><smiles>[R]N([R])CC(O)COCCc1ccccc1</smiles>

a: $\mathrm{R}=\mathrm{H}, \mathrm{R}_{1}=\left(\mathrm{CH}_{2}\right)_{2} \mathrm{OH} ; \mathbf{b}: \mathrm{R}=\mathrm{H}, \mathrm{R}_{1}=\left(\mathrm{CH}_{2}\right)_{3} \mathrm{OH} ; \mathbf{c}: \mathrm{R}=\mathrm{H}, \mathrm{R}_{1}=\mathrm{C}\left(\mathrm{CH}_{3}\right)_{2} \mathrm{CH}_{2} \mathrm{OH} ; \mathbf{d}: \mathrm{R}=\mathrm{R}_{1}=\mathrm{CH}_{2} \mathrm{CH}_{2} \mathrm{OH}$

SCHEME 2. Synthesis of aromatic aminoalcohols 5a-d from phenethyl alcohol. 

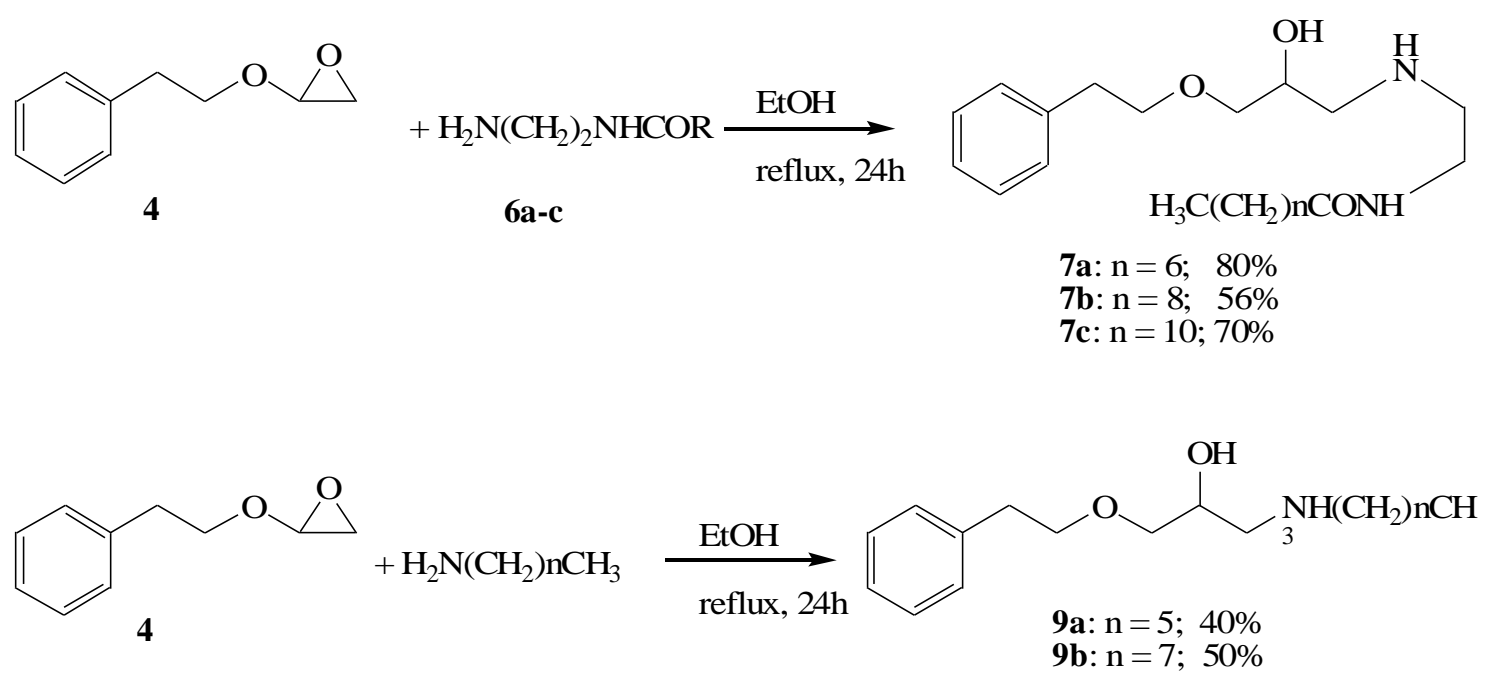

SCHEME 3. Synthesis of aminoalcohols 7a-c and $9 \mathbf{a}, \mathbf{b}$.

\section{Biological Assay}

In this study, promastigotes of L. chagasi (MHOM/Br/74/PP75), L. amazonensis (IFLA/Br/67/PH8), and L. major (MRHO/SU/59/P) were used. The viability of the promastigotes was determined by the colorimetric 3-(4,5-dimethylthiazol-2-yl)-2,5-diphenyl-tetrazolium bromide (MTT) method based on tetrazolium salt reduction by mitochondrial dehydrogenases[23]. The results are expressed as the concentration inhibiting the parasite growth by $50 \%\left(\mathrm{IC}_{50}\right)$ after a 3-day incubation period with the tested compound. Amphotericin B (Cristália-São Paulo) was used as the reference standard. $\mathrm{IC}_{50}$ values were obtained from at least two independent experiments performed in triplicate, and GraFit Version 5 software (Erithacus Software Ltd., Horley, U.K.) was used for the analysis of the data.

\section{RESULTS AND DISCUSSION}

Among the evaluated compounds, the less lipophilic $N$-phenethylethanolamine 3a and its analogues $\mathbf{3 b}$-d were inactive against all Leishmania species promastigotes at tested concentrations (Table 1). In the aminodiol series 5a-d, compounds $\mathbf{5 a}$ and $\mathbf{5 c}$ showed a good activity against $L$. major promastigotes $\left(\mathrm{IC}_{50}\right.$ values of 13.6 and $4.6 \mu \mathrm{M}$, respectively). Lipophilic aminoalcohols 7a-c, bearing an aliphatic amide moiety, were active against both $L$. amazonensis and L. major promastigote forms. Compound $\mathbf{7 b}$, a decanoylethylenediamine derivative, showed the best activity against L. amazonensis $\left(\mathrm{IC}_{50}\right.$ of $\left.18.6 \mu \mathrm{M}\right)$ and L. major $\left(\mathrm{IC}_{50}\right.$ of $\left.5.2 \mu \mathrm{M}\right)$.

The two alkylated aminoalcohols $(\mathbf{9 a}, \mathbf{b})$ displayed the best inhibitory activity against all Leishmania promastigotes tested, with $\mathrm{IC}_{50}$ values ranging from 0.7 to $49.0 \mu \mathrm{M}$. Compound $\mathbf{9 b}$, bearing an octyl chain, was the most efficient against the three species with $\mathrm{IC}_{50}$ values of $18.5,0.7$, and $30.0 \mu \mathrm{M}$, for $L$. amazonensis, L. major, and L. chagasi promastigote forms, respectively.

From these results, we can observe a pattern of sensitivity of Leishmania species to the tested compounds. L. major promastigotes were the most sensitive to the tested aminoalcohols, with $\mathrm{IC}_{50}$ values $<20 \mu \mathrm{M}$. This strain also showed the smallest $\mathrm{IC}_{50}$ between the 14 compounds tested $(0.7 \mu \mathrm{M})$. This pattern of sensitivity of the parasites to different drugs is not surprising as it has been reported in several studies[23,24,25,26]. 
TABLE 1

In vitro $50 \%$ Inhibitory Activity against Promastigotes of Three Leishmania Species

\begin{tabular}{|c|c|c|c|}
\hline \multirow{2}{*}{ Compounds } & \multicolumn{3}{|c|}{ IC50 ( $\mu \mathrm{M})$} \\
\hline & L. amazonensis & L. major & L. chagasi \\
\hline$\underline{3 a}$ & $>87.0$ & $>87.0$ & $>87.0$ \\
\hline$\overline{3 b}$ & $>87.0$ & $>87.0$ & $>87.0$ \\
\hline $3 c$ & $>87.0$ & $>87.0$ & $>87.0$ \\
\hline 3d & $>87.0$ & $>87.0$ & $>87.0$ \\
\hline $5 a$ & $>87.0$ & $13.6 \pm 2.2$ & $>87.0$ \\
\hline $5 b$ & $>87.0$ & $>87.0$ & $>87.0$ \\
\hline $5 c$ & $>87.0$ & $4.6 \pm 5.3$ & $>87.0$ \\
\hline $5 d$ & $>87.0$ & $>87.0$ & $>87.0$ \\
\hline $7 a$ & $49.0 \pm 0.7$ & $14.4 \pm 1.4$ & N.T.* \\
\hline $7 b$ & $18.6 \pm 4.6$ & $5.2 \pm 0.3$ & $>87.0$ \\
\hline 7c & $46.4 \pm 2.0$ & $19.7 \pm 2.9$ & $>87.0$ \\
\hline $9 a$ & $37.3 \pm 3.0$ & $11.4 \pm 0.2$ & $27.5 \pm 0.3$ \\
\hline $9 b$ & $18.5 \pm 2.9$ & 0.72 & $30.0 \pm 0.2$ \\
\hline$A m B^{* \star}$ & 0.4 & 0.32 & $1.9 \pm 0.2$ \\
\hline
\end{tabular}

The results point to the importance of lipophilicity for antileishmanial activity: the two most active compounds are alkylated (9b) or acylated (7b) aminoalcohols, while none of the less lipophilic compounds $(\underline{\mathbf{3 a}-\mathbf{d}})$ was active.

\section{CONCLUSION}

This work describes the preparation and biological evaluation of several aminoalcohols prepared by the reaction of aromatic halides and aromatic glycidyl ethers with aminoalcohols (3a-d and 5a-d), aliphatic amides (7a-c), and aliphatic amines (9a,b). Five compounds (7a-c and 9a,b) displayed a good activity against $L$. amazonensis, seven compounds $(\mathbf{5 a}, \mathbf{5 c}, \mathbf{7 a - c}$, and $9 \mathbf{9 a}, \mathbf{b})$ were active against $L$. major, and only two $(\mathbf{9 a}, \mathbf{b})$ were active against $L$. chagasi. These results show that the lipophilicity of the respective aminoalcohols is of great importance for antileishmanial activity, as compounds $\mathbf{7 b}$ and $\mathbf{9 b}$, containing aliphatic side chains with 10 or eight carbons, showed the best activity against $L$. amazonensis and $L$. major promastigote forms.

\section{ACKNOWLEDGMENTS}

The authors gratefully acknowledge UFJF, CAPES, and CNPq for fellowships. This research was supported by FAPEMIG. 


\section{REFERENCES}

1. WHO (2005) Tropical Disease Research. Progress 2003-2004. Special Program for Research and Training in Tropical Diseases. World Health Organization, Geneva.

2. Bern, C., Maguire, J.H., and Alvar, J. (2008) Complexities of assessing the disease burden attributable to Leishmaniasis. PLoS Negl. Trop. Dis. 2, 1-8.

3. Jeronimo, S.M.B., de Queiroz Sousa, A., and Pearson, R.D. (2006) Leishmaniasis. In Tropical Infectious Diseases: Principles, Pathogens and Practice. Guerrant, R.L., Walker, D.H., and Weller, P.F., Eds. Churchill Livingstone Elsevier, Edinburgh. pp. 1095-1113.

4. Alvar, J., Yactayo, S., and Bern, C. (2006) Leishmaniasis and poverty. Trends Parasitol. 22, $552-557$.

5. Cruz, A.K., De Toledo, J.S., Falade, M., Terrão, M.C., Kamchonwongpaisan, S., Kyle, D.E., and Uthaipibull, C. (2009) Current treatment and drug discovery against Leishmania spp. and Plasmodium spp.: a review. Curr. Drug Targets 10, 178-192.

6. Frézard, F., Demicheli, C., and Ribeiro R.R. (2009) Pentavalent antimonials: new perspectives for old drugs. Molecules 14, 2317-2336

7. Del Olmo, E.M., Alves, M., Lopéz, J.L., Inchaustti, A., Yaluff, G., and De Arias, A.R. (2002) Leishmanicidal activity of some aliphatic diamines and amino-alcohols. Bioorg. Med. Chem. Lett. 12, 659-662.

8. Reis, R.C.N., Coimbra, E.S., Almeida, C.G., Júnior, W.V., De Almeida, A.C.F., Forezi, L.S.M., Almeida, M.V., and Le Hyaric, M. (2008) Antileishmanial activity of aldonamides and $N$-acyl-diamine derivatives. TheScientificWorldJOURNAL 8, 752-756.

9. Costa, C.F., Coimbra, E.S., Braga, F.G., Reis, R.C.N., Silva, A.D., and De Almeida, M.V. (2009) Preparation and antileishmanial activity of lipophilic $N$-alkyl diamines. Biomed. Pharmacother. 63, 40-42.

10. Labadie, G.R., Choi, S.R., and Avery, M.A. (2004) Diamine derivatives with antiparasitic activities. Bioorg. Med. Chem. Lett. 14, 615-619.

11. Rebollo, O., del Olmo, E., Ruiz, G., López-Pérez, J.L., Giménez, A., and San Feliciano, A. (2008) Leishmanicidal and trypanocidal activities of 2-aminocyclohexanol and 1,2- cyclohexanediamine derivatives. Bioorg. Med. Chem. Lett. 18, 184-187.

12. Taylor, M.C., Kaur, H., Blessington, B., Kelly, J.M., and Wilkinson, S.R. (2008) Validation of spermidine synthase as a drug target in African trypanosomes. Biochem. J. 15, 563-569.

13. Heby, O., Persson, L., and Rentala, M. (2007) Targeting the polyamine biosynthetic enzymes: a promising approach to therapy of African sleeping sickness, Chagas disease, and leishmaniases. Amino Acids 33, 359-366.

14. Baiocco, P., Franceshini, S., Ilari, A., and Colotti, G. (2009) Trypanothione reductase from Leishmania infantum: cloning, expression, purification, crystallization and preliminary X-ray data analysis. Protein Pept. Lett. 16, $196-200$.

15. Castro-Pinto, D.B., Genestra, M., Menezes, G.B., Wagahabi, M., Gonçalves, A., De Nigris Del Cistia, C., Sant'Anna, C.M., Leon, L.L., and Mendonça-Lima, L. (2008) Cloning and expression of trypanothione reductase from a New World Leishmania species. Arch. Microbiol. 189, 375-384.

16. Basselin, M. and Robert-Gero, M. (1998) Alterations in membrane fluidity, lipid metabolism, mitochondrial activity, and lipophosphoglycan expression in pentamidine-resistant Leishmania. Parasitol. Res. 84, 78-83.

17. Long, D., Church, T.J., Jacobsen, J.R., Jiang, L., Saito, DR., and Stergiades, I. (2007) Preparation of 8azabicyclo[3.2.1]octane derivatives for use in pharmaceutical compositions as opioid receptor antagonists PCT. Int. Appl. WO 2007103187 A2 20070913.

18. Aranapakam, V., Davis, J.M., Grosu, G.T., Baker, J., Ellingboe, J., Zask, A., Levin, J.I., Sandanayaka, V.P., Du, M., Skotnicki, J.S., DiJoseph, J.F., Sung, A., Sharr, M.A., Killar, L.M., Walter, T., Jin, G., Cowling, R., Tillett, J., Zhao, W., McDevitt, J., and $\mathrm{Xu}, \mathrm{Z}$. (2003) Synthesis and structure-activity relationship of $N$-substituted 4arylsulfonylpiperidine-4-hydroxamic acids as novel, orally active matrix metalloproteinase inhibitors for the treatment of osteoarthritis. J. Med. Chem. 46, 2376-2396.

19. Eckstein, M., Zajaczkowska, J., Krupinska, J., and Michna, M. (1986) Derivatives of 2-N-arylalkylamino-2-methyl-1propanol with antiarrhythmic activity. Pol. J. Pharmacol. Pharm. 38, 215-220.

20. Mauleon, D., Pujol, M., and Rosell, G. (1988) $\beta$-Adrenergic antagonists: $N$-alkyl and $N$ amidoethyl(arylalkoxy)propanolamines related to propranolol. Eur. J. Med. Chem. 23, 421-426.

21. Almeida, C.G., Darbois, G.D., Amaral, L.M., Diniz, C.G., and Le Hyaric, M. (2010) Relationship between structure and antibacterial activity of lipophilic $N$-acyldiamines. Biomed. Pharmacother. 64, 287-290.

22. General method: Glycidylether $4(4 \mathrm{mmol})$ in ethanol $(5 \mathrm{~mL})$ was added under reflux to a solution of aminoalcohol $(12 \mathrm{mmol})$, amide $(8 \mathrm{mmol})$, or amine $(8 \mathrm{mmol})$ dissolved in $100 \mathrm{~mL}$ of ethanol. Pure compounds were obtained after extraction with $\mathrm{CH}_{2} \mathrm{Cl}_{2}$ and column chromatography on silicagel $\left(\mathrm{CH}_{2} \mathrm{Cl}_{2}: \mathrm{MeOH}\right)$. All spectra were performed in $\mathrm{CDCl}_{3}$ using TMS as reference. ${ }^{13} \mathrm{C}$ NMR: 5a $(139.1 ; 129.0-128.5 ; 126.6 ; 73.7 ; 72.4 ; 69.3 ; 61.2 ; 52.0 ; 36.4) ; 5 \mathbf{b}$ $(138.9 ; 129.0-128.5 ; 126.4 ; 73.6 ; 72.4 ; 68.9 ; 63.1 ; 52.2 ; 49.0 ; 36.2 ; 30.9) ; \mathbf{5 c}(138.9 ; 129.0-127.5 ; 126.4 ; 73.7 ; 72.4$; $69.9 ; 68.6 ; 53.6 ; 44.4 ; 36.3 ; 23.1) ; \mathbf{5 d}(138.9 ; 129.0-128.5 ; 126.4 ; 73.2 ; 72.5 ; 67.9 ; 59.5 ; 58.4 ; 57.5 ; 36.3) ; 7 \mathbf{a}(173.9$; $138.9 ; 129.0-128.5 ; 126.4 ; 73.5 ; 72.4 ; 68.7 ; 51.8 ; 48.9 ; 38.8 ; 36.9 ; 36.3 ; 31.8-22.7 ; 14.2) ; 7 \mathbf{b}(174.1 ; 138.9 ; 129.0-$ $128.5 ; 126.5 ; 73.4 ; 72.5 ; 68.4 ; 51.8 ; 38.5 ; 36.9 ; 36.3 ; 32.0-22.8 ; 14.2) ; 7$ c $(174.1 ; 13.8 ; 129.0-128.5 ; 126.4 ; 76.7$; $72.5 ; 68.3 ; 51.8 ; 48.9 ; 38.5 ; 36.8 ; 36.3 ; 32.0-22.8 ; 14.2)$; 9a $(139.0 ; 129.0-128.5 ; 126.5 ; 73.7 ; 72.5 ; 68.8 ; 52.1 ; 50.0$; $36.4 ; 31.9-22.8 ; 14.2) ; 9 b(139.0 ; 129.0-128.5 ; 126.4 ; 73.3 ; 72.4 ; 69.5 ; 58.1 ; 55.8 ; 36.4 ; 32.0-22.8 ; 14.2)$. 
23. Braga, F.G., Coimbra, E.S., Matos, M.O., Carmo, A.M.L., Cancio, M.D., and Da Silva, A.D. (2007) Synthesis and biological evaluation of some 6-substituted purines. Eur. J. Med. Chem. 42, 530-537.

24. Escobar, P., Sangeeta, M., Marques, C., and Croft, S.L. (2002) Sensitivities of Leishmania species to hexadecylphosphocholine (miltefosine), ET-18-OCH3 (edelfosine) and amphotericin B. Acta Trop. 81, 151-157.

25. Croft, S.L., Seifert, K., and Yardley, V. (2006) Current scenario of drug development for leishmaniasis. Indian J. Med. Res. 123, 399-410.

26. Croft, S.L., Barrett, M.P., and Urbina, J.A. (2005) Chemotherapy of trypanosomiases and leishmaniasis. Trends Parasitol. 21, 508-512.

This article should be cited as follows:

Corrales, R.N.R., Pinheiro, L.S., Coimbra, E.S., Da Silva, A.D., and Le Hyaric, M. (2010) Synthesis and antileishmanial activity of lipophilic aromatic aminoalcohols. TheScientific WorldJOURNAL 10, 1067-1072. DOI 10.1100/tsw.2010.106. 

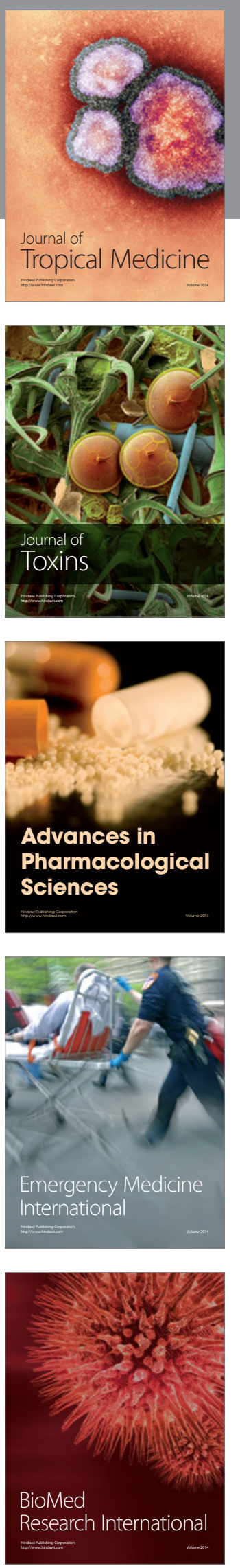
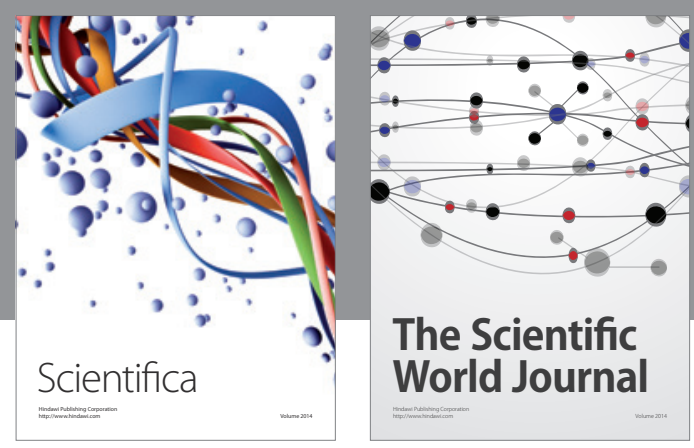

The Scientific World Journal
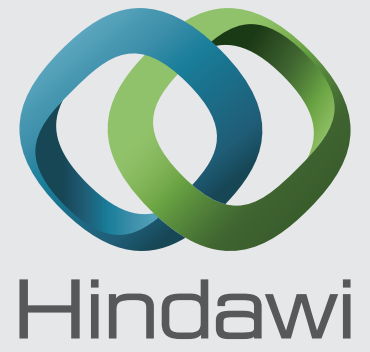

Submit your manuscripts at

http://www.hindawi.com
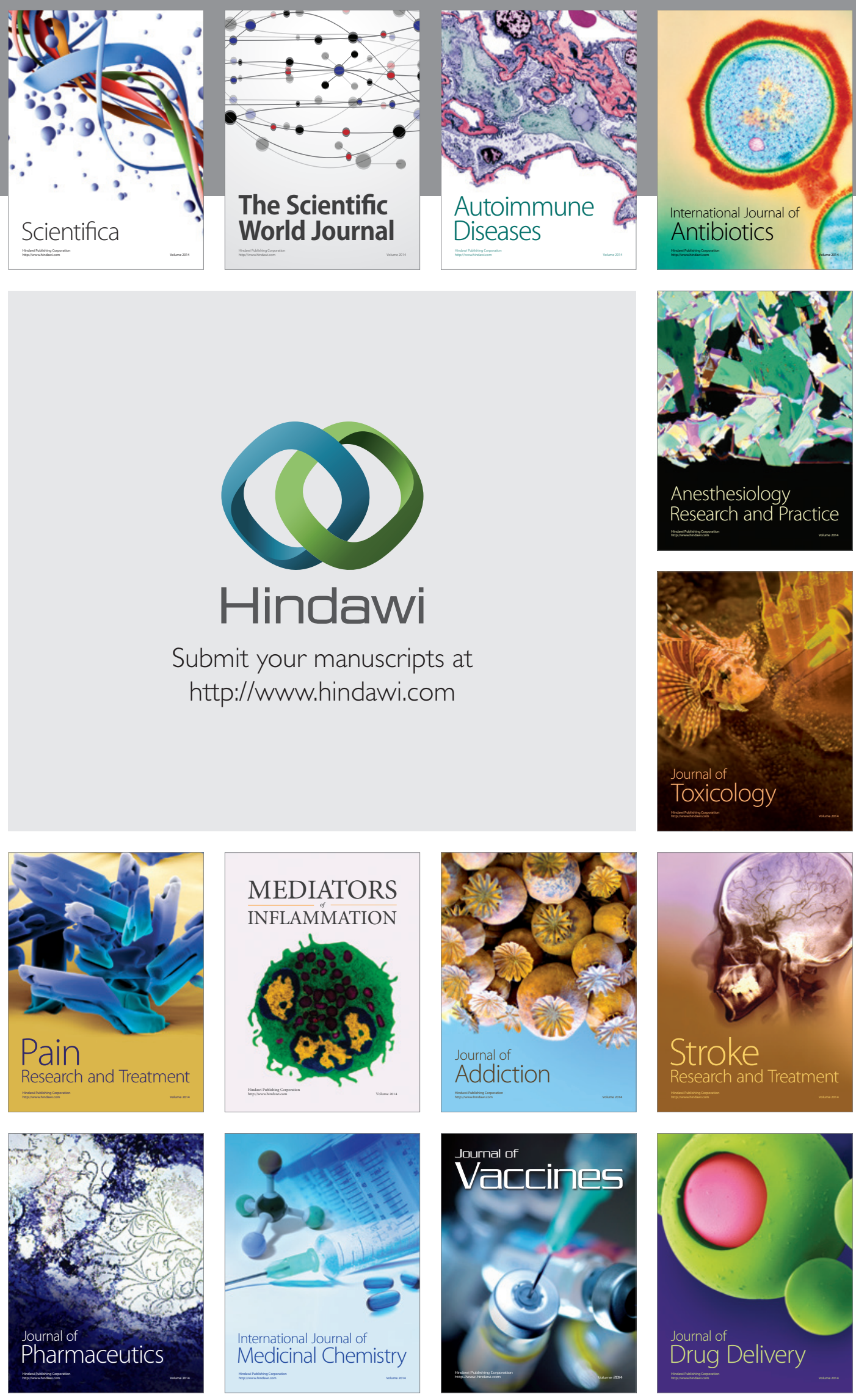